\title{
Criminal law as a preventative tool of environmental regulation: compliance versus deterrence
}

\author{
PATRICK BISHOP*
}

University of Wales, Swansea

\begin{abstract}
$\underline{A B S T R A C T}$
The effective enforcement of environmental law is an issue which continues to engender considerable academic debate. The conclusions that may be drawn from such debate will have implications not only for the future of environmental law but also the wider regulatory reform agenda. This article commences with several noncontentious propositions. First, any regulatory regime ought to place considerable emphasis on preventing harm; within the context of environmental law, this view is encapsulated by the preventative principle. Secondly, one may be tempted to treat the criminal law as a purely reactive or curative mechanism were it not for the deterrent effect associated with the imposition of criminal sanctions. Therefore, the initial premise is that if environmental law is to become more preventative in scope, policymakers ought to consider how the deterrent effect of environmental criminal law may be bolstered. Academic publications and official reports are replete with assertions that the fines imposed by the courts for environmental crime are lamentably low. A preoccupation with the level of fine may lead one to overlook the fundamental importance of the likelihood of apprehension as an essential ingredient of the deterrence formula. Mainstream criminological discourse provides clear evidence that the probability of apprehension has a greater influence on deterrence than severity of sanction. In this context, the enforcement style adopted by the relevant enforcement agency is crucial; in particular, whether the style adopted angments the perception that apprehension is more probable. This article proceeds to argue that many of the assumptions on which the compliance style is based may be questioned, if not totally undermined. It is contended that a transition from compliance-orientated enforcement towards an approach more focused on deterrence has the potential to enhance the deterrent, and by extension the preventative effect, of environmental criminal law.
\end{abstract}

\footnotetext{
Centre for Environmental and Energy Law and Policy, School of Law, Swansea University, Singleton Park, Swansea SA2 8PP, p.bishop@swansea.ac.uk. The author would like to thank Stuart Macdonald, Karen Morrow and Mark Stallworthy for their advice and comments on an earlier draft of this article. Naturally, any errors or omissions are entirely my own.
} 


\section{Introduction}

T he effective enforcement of environmental law continues to engender considerable debate. ${ }^{1}$ Academic discourse on the subject has been supplemented by the publication of the Hampton ${ }^{2}$ and Macrory Reports, ${ }^{3}$ which ultimately led to the enactment of the Regulatory Enforcement and Sanctions Act 2008. The underlying premise of these publications is that the use of conventional criminal sanctions alone can be an ineffectual mechanism for ensuring compliance with regulatory law. To a greater or lesser extent, the criticisms levelled at the criminal law are based on the assertion that the imposition of traditional sanctions does not adequately prevent regulatory breaches. While Macrory argues convincingly in favour of an enhanced sanctioning "tool kit", the new penalties advocated by the report and contained in the Act are seen as a supplement to (rather than replacement of) conventional criminal sanctions. Thus, while increased flexibility in the range of sanctions can be lauded for attenuating the hitherto binary nature of regulatory enforcement, it seems that the imposition of traditional criminal sanctions will remain an important weapon in the regulator's armoury. It is not suggested here that a greater range of activities which have the potential to damage the environment or cause environmental harm ought to be criminalised $;{ }^{4}$ this article will simply seek to explore how the enforcement style adopted by a regulator may be modified so that the potential preventative effect of the criminal law is increased substantially. In essence, it will be argued that a move away from compliance-orientated enforcement strategies to an approach based on deterrence has the potential to alleviate many of the problematic aspects of regulatory non-compliance. This article will make a number of arguments; first, it will be uncontentiously submitted that the imposition of expost facto criminal liability is able to operate in a preventative manner via the concept of deterrence. It will be further argued that simply increasing the severity of sanctions can only ever represent a partial solution to non-compliance. Finally, as a matter of enforcement policy, it is contended that the use of a strategy which places greater emphasis on deterrence (as opposed to compliance) has the potential to bolster the preventative aspects of the criminal law.

\section{The preventative imperative}

The preventative principle $^{5}$ can be described succinctly as the requirement that environmental harm/pollution be prevented in advance rather than remedied after the event and, as such, is simply an embodiment of the almost universally accepted adage that "prevention is better than cure". The desirability of preventing environmental damage rather than reacting to it is beyond doubt, to the extent that one commentator has described the preventative principle thus: "a beacon for environmental law at both the international

1 See e.g. K Hawkins, Environment and Enforcement: Regulation and the social definition of pollution (Oxford: Clarendon Press 1984); K Hawkins and J Thomas (eds), Enforcing Regulation (Boston: Kluwer-Nijhoff 1984); B Hutter, Compliance: Regulation and Environment (Oxford: Clarendon Press 1997); K Hawkins, Law as a Last Resort: Prosecution in a regulatory agency (Oxford: OUP 2002).

2 P Hampton, Reducing Administrative Burdens: Effective inspection and enforcement (the Hampton report) (Norwich: HMSO, March 2005).

3 R B Macrory, Regulatory Justice: Making sanctions effective (the Macrory report) (London: Better Regulation Executive, November 2006).

4 For an analysis of how some inherently anti-ecological activities are sanctioned by the law, see M Halsey, "Environmental crime: towards an eco-human rights approach" (1997) 8(3) Current Issues in Criminal Justice 217.

5 For an analysis of the principle of prevention, see $\mathrm{N}$ de Sadeleer, Environmental Principles: From political slogans to legal rules (Oxford: OUP 2002), pp. 61-91; for environmental principles in general see, R Macrory (ed.), Principles of European Environmental Law (Groningen: Europa Law Publishing 2004); S Tromans, "High talk and low cunning: putting environmental principles into legal practice" (1995) JPL 778. 
level and national legal orders: a sort of golden rule". ${ }^{6}$ On this basis it may be considered that the criminal law and the corresponding imposition of criminal sanctions is a paradigm reactive mechanism. Many environmental offences are inchoate; in such cases there is no requirement that harm has occurred as a condition precedent of criminal liability, for example, one may be guilty of the offence of causing poisonous, noxious or polluting matter to enter controlled waters ${ }^{7}$ notwithstanding that the discharge has not actually harmed the river or life within the river. ${ }^{8}$ Despite this, the criminal law is responsive in the sense that potential liability is "triggered" only where an environmental offence has been committed. As Hill has asserted: "A criminal prosecution is always a reactive event.", Despite this apparent reactive element to the criminal law, it is axiomatic that the imposition of expost liability (criminal or civil) can operate in an ex ante manner by having a dissuasive or deterrent effect on potential polluters. ${ }^{10}$ The ability of the criminal law to operate preventively has been explicitly recognised by the EU, a perusal of the directive on shipsource pollution and the introduction of penalties for infringements ${ }^{11}$ and the proposed directive on the protection of the environment through the criminal law ${ }^{12}$ reveals the recurrent use of the word "dissuasive", i.e. it is clearly recognised that the imposition of sufficiently punitive criminal sanctions may operate to prevent environmental crime. In this sense the designation of particular forms of conduct as "criminal" always entails a preventative element. ${ }^{13}$ It is manifestly clear that the criminal law has both deterrent and retributive functions; it is equally apparent that both functions are not mutually exclusive, i.e. the imposition of a punitive sanction is capable of deterring others from engaging in the prohibited conduct. This article will proceed to analyse the extent to which regulatory criminal law and regulatory enforcement are capable of functioning in a manner which maximises the deterrent and, by extension, the preventative effect of environmental law.

\section{Environmental criminal law}

The terms "environmental criminal law" and "environmental crime" are wide ranging and could feasibly include casual fly-tipping or the consequences of a major industrial accident with almost innumerable substantive and administrative offences situated between these opposing ends of the spectrum. ${ }^{14}$ The breadth of environmental crime is problematic for anyone wishing to identify and elucidate general principles. As such, most of the empirical

6 de Sadeleer, Environmental Principles, n. 5 above, p. 89. The preventative principle is a guiding principle of EU environmental law by virtue of Art. 174(2) of the EC Treaty.

7 Water Resources Act 1991, s. 85(1).

8 See the dictum of Bryant J in National Rivers Authority v Egger (1992) where it was stated: "One looks at the nature of the discharge and one says, is that discharge capable of causing harm to a river, in the sense of causing damage to the uses to which a river might be put; damage to animal, vegetable or other - if there is such other life which might live in a river, or damaging that river aesthetically." Reported in R Burnett-Hall, Environmental Law (London: Sweet \& Maxwell 1995) pp. 351-4.

9 M Hill, "Prosecuting environmental crime" in W Upton (ed.), The Changing Role of Environmental Law (London: United Kingdom Environmental Law Association 2000), p. 29.

10 M Faure (ed.), "Deterrence, insurability, and compensation in environmental liability", vol. 5 of Torts and Insurance Law (New York: Springer 2003), pp. 19-20.

11 Directive 2005/35/EC. See also the Council Framework Decision 2005/667/JHA to strengthen the criminal law framework for the law against ship-source pollution.

$12 \operatorname{COM}(2007) 51$ final, available at: http://eurlex.europa.eu/LexUriServ/site/en/com/2007/com2007_0051en01.pdf.

13 By virtue of the Criminal Justice Act 2003, s. 142(b), one of the stated purposes of sentencing is the reduction of crime.

14 See, generally, K Brickey, "Environmental crime at the crossroads: the intersection of environmental and criminal law theory" (1996) 71 Tulane Law Review 487. 
research in this area has focused on a particular offence or particular type of offender. The focus of the current enquiry is itself relatively broad but is largely limited to corporate offenders under typical pollution control regimes. Nevertheless, this article's central argument, that deterrence-based approaches augment the perception that apprehension is more likely and therefore enhances the deterrent effect of the law, is sufficiently malleable to apply, to a greater or lesser extent, to most environmental crimes.

Environmental offences have proliferated since the inception of modern environmental law and are an integral feature of most "command and control" regulatory systems. Despite the increased use of alternative methods to achieve environmental policy goals, such as incentives and economic instruments, the use of direct regulation ${ }^{15}$ is likely to remain as the bedrock of environmental law in England and Wales. As such, an essential ingredient of any regulatory regime is the availability of sanctions for non-compliance. ${ }^{16}$ Macrory, in his report on regulatory justice, has recommended, inter alia, increased flexibility in the range of sanctions available to enforcement agencies, some of his recommendations are given effect in the Regulatory Enforcement and Sanctions Act 2008. A common feature of the new sanctions, such as fixed monetary penalties, is that they can be unilaterally imposed by an enforcement agency without recourse to the criminal courts and the corresponding due process safeguards which can make such a course of action time-consuming and expensive. ${ }^{17}$ Despite this, a sanction will only be imposed where a violation of a regulatory statute has occurred ${ }^{18}$ and thus the new sanctioning tool kit envisaged by Macrory will continue to operate within the context of a criminal law framework. Further, the overall focus of the report is on regulatory sanctions and as such the new mechanisms suggested to ensure compliance are punitive in effect - they impose a form of punishment as opposed to providing incentives. 19

Even if environmental law were to develop so that emphasis was shifted from command and control regulation to alternative methods (economic instruments for example), then it is submitted that the criminal law would remain of crucial importance. To illustrate by way of example, in England and Wales, a landfill tax was introduced in 1996, ${ }^{20}$ one of the stated purposes of the tax (a classic economic instrument) was to encourage alternative methods of waste disposal, such as recycling and composting. ${ }^{21}$ One unintended

15 For a persuasive defence of direct regulation, see R Macrory, "Regulating in a risky environment", (2001) 54 Current Legal Problems 619.

16 Ibid., at p. 619. For a discussion of alternative methods of enforcement such as the common law, judicial review and human rights legislation, see L Hagger, "Current environmental enforcement issues: some international developments and their implications for the UK" (2000) 2 Environmental Law Review 23.

17 The use of such penalties is not without precedent in environmental law. Examples include: fixed penalty notices are utilised in respect of the offence of allowing a dog to defecate on designated land under the Dogs (Fouling of Land) Act 1996, ss 3-4; the Noise Act 1996 (as amended by the Anti-Social Behaviour Act 2003) permits a local authority to issue a fixed penalty notice in relation to specified offences under the Act; the Environmental Protection Act 1990, s. 88, allows the use of fixed penalties in relation to the offence of littering under s. 87.

18 Regulatory Enforcement and Sanctions Act 2008, s. 39(2).

19 The distinction between coercive sanctions and non-coercive incentives can become blurred. See J Brigham and D Brown, "Distinguishing penalties and incentives" (1980) 2(1) Law and Policy Quarterly 5.

20 Introduced by the Finance Act 1996: the detailed regime is provided for by the Landfill Tax Regulations 1996, SI 1996/1527; Landfill Tax (Qualifying Materials) Order 1996, SI 1996/1529; and Landfill Tax (Contaminated Land) Order 1996, SI 1996/1528. Landfill tax for active waste is currently set at $£ 18$ per tonne with anticipated increases of $\AA^{3}$ per annum up to a maximum of $£^{35}$ per tonne.

21 J Morris, P Phillips and A Read, "The UK Landfill Tax: an evaluation of the first three years" (2000) 2 Environmental Law Review 150, pp. 153-6. 
consequence of the introduction of the tax was an increase in fly-tipping. ${ }^{22}$ In effect, the success of this alternative method of achieving an environmental goal is dependent on the criminalisation of any illegitimate method $^{23}$ which can be utilised to circumvent the landfill tax. In summary, the criminal law is of crucial importance and as such, if environmental law is to become more preventative in scope it is essential that policymakers consider how the deterrent effect of the law may be bolstered.

\section{Deterrence}

The concept of deterrence ${ }^{24}$ is fundamentally premised on the notion that the infliction of a punitive sanction is capable of influencing the future conduct of potential lawbreakers. Sentencing based on deterrence has an instrumental or consequentialist rationale where the paramount objective is the prevention of future crime. A utilitarian formula provides a justification for punishing individuals severely to deter effectively others from criminal acts; in one sense the classic "end justifies the means" argument where proportionality has little relevance. ${ }^{25}$ This ability to instigate behavioural change is capable of operating directly, where a natural or legal person is deterred from future violations via the imposition of a sanction and the desire to avoid future sanctions (specific deterrence and incapacitation) 26 or indirectly, where an example is made of specific deviants so as to deter other individuals from future deviance (general deterrence). ${ }^{27}$ Two further sub-categories of deterrence may be identified, namely initial deterrence and marginal deterrence. The former concerns the effect of prohibiting conduct previously lawful, while the latter is concerned with the deterrent effect of changes in enforcement policy and/or sanctions in relation to conduct already prohibited. While the simple term "deterrence" is used throughout this article, the central focus is on marginal deterrence. The extent of the deterrent effect associated with the imposition of criminal sanctions is a matter of fierce academic debate. An extreme viewpoint is that the criminal law has no deterrent effect. ${ }^{28}$ However, the general consensus would seem to be that punitive sanctions are capable of deterring and thus the debate has largely focused on the degree of any potential deterrent effect, as Ehrlich has commented: "it is perhaps the extent of the deterrent effect of law enforcement, not its mere existence, that is principally at issue". 29

The question of why people commit crime has proved to be as unavoidable as any other and requires, inter alia, sociological and psychological examination. Criminological discourse on the subject has concentrated, to a large extent, on non-environmental crimes. Whereas

22 M Watson, "Environmental offences: the reality of environmental crime" (2005) 7 Environmental Law Review 190, p. 195; S Bell and D McGillivray, Environmental Law 6th edn (Oxford: OUP 2006), p. 614; P. Stookes, A Practical Approach to Environmental Law (Oxford: OUP 2005), p. 344.

23 S. 33(1) of the Environmental Protection Act 1990 and the Waste Management Licensing Regulations 1994, reg. 1(3) and Sch. 4, create various criminal offences associated with the disposal etc of waste.

24 See, generally, A Ashworth and A von Hirsch (eds), Principled Sentencing: Theory and policy 2nd edn (Oxford: Hart Publishing 1998), ch. 2.

25 A Ashworth, "Sentencing" in M Maguire, R Morgan and R Reiner (eds), The Oxford Handbook of Criminology 2nd edn (Oxford: OUP 1997), p. 1098.

26 Incapacitation refers to the removal of an individual actor's ability to commit crime, usually via imprisonment. In most environmental crime prosecutions, the defendant will be a corporation and is therefore imprisonment is not an option. However, incapacitation can still occur via the removal of a licence where the activity pursued by the defendant requires prior authorisation.

27 See, generally, K Williams and R Hawkins, "Perceptual research on general deterrence: a critical review" (1986) 20(4) Law and Society Review 545.

28 I Ehrlich, "The deterrent effect of criminal law enforcement" (1972) 1 Journal of Legal Studies 259, at p. 260.

29 Ibid., at p. 261. 
traditional mens rea crimes such as theft, burglary and murder are committed by individuals, ${ }^{30}$ environmental crimes can be committed by individuals and corporations and it is the latter who are most often prosecuted by enforcement agencies. When an environmental crime is committed by a corporation then the obvious problem from a deterrence perspective is that incarceration is seldom an option. However, while the individual and corporation may both exercise bounded rationality, the inherent difference in character between natural and legal persons arguably enhances the deterrent effect of the criminal law in a corporate context. Many typical mens rea crimes are committed by individuals as a result of an impulse which is difficult, if not impossible to control. The heroin addict who steals to maintain a supply of drugs and the archetypal "crime of passion" are just two such examples. Thus, for crimes committed in such circumstances the offender is unlikely to reflect upon the potential consequences of his or her actions - this viewpoint is bolstered to some extent by empirical studies on the deterrent effect of capital punishment. ${ }^{31}$ Corporations, on the other hand, are more likely to operate as rational economic calculators, heuristically weighing up the benefits and disadvantages of transgressing the law and are thus more likely to be deterred by the real or perceived consequences of criminal sanctions. In distinguishing individual and corporate criminality in this manner, one needs to avoid oversimplification. First, in comparison to individuals, corporations will generally possess greater resources with which to pay fines and combat adverse publicity. Secondly, not all individual offenders commit crime because of their innate tendencies; career criminals whose crimes are motivated by economic gain clearly exist. Similarly, it cannot automatically be assumed that a corporation will act as a dispassionate economic maximiser; particular firms may well propagate an ethos or personality which tends towards criminal conduct. These exceptions notwithstanding, it is contended that in many instances corporations are more likely to be susceptible to deterrence-based strategies than is the case with individual offenders.

The potential deterrent effect of the criminal law is a subject which requires both theoretical examination and empirical investigation; this article concentrates on the theoretical debate for the following reason. From a methodological perspective, empirical studies in this area are problematic. First, when one attempts to measure the deterrent effect of the criminal law one is faced with measuring an event that has not occurred. ${ }^{32}$ Second, if it can be satisfactorily determined that a particular crime is not being committed, a causal relationship between a particular sanction and the paucity of a specific offence is notoriously difficult to establish. One is faced with the difficulty of safely ascribing non-offending to the deterrent effect of a criminal sanction and not to one of the other myriad reasons that inhibit the commission of crime, such as an inherent respect for the law, peer disapproval etc. ${ }^{33}$

30 In certain circumstances corporations are capable of committing crimes with a mens rea element. N.B. Corporate Manslaughter and Corporate Homicide Act 2007.

31 In a well-known study conducted by sociologist Thorsten Sellin, in which the correlation of homicide rates in retentionist and abolitionist states was analysed, it was concluded that the existence of the death penalty has no enhanced deterrent effect. See T Sellin, "Homicides in retentionist and abolitionist states" in T Sellin (ed.), Capital Punishment 135 (New York: Harper \& Row 1967). For a more contemporary review of the relevant literature see J Donohue and J Wolfers, "Uses and abuses of empirical evidence in the death penalty debate" (2005) 58 Stanford Law Review 791. Due to the methodological difficulties of studies in this area, one needs to treat empirical data with caution, see $\mathrm{n} .33$ below and accompanying text.

32 H Jacob, "Deterrent effects of formal and informal sanctions" (1980) 2(1) Law and Policy Quarterly 61, at p. 61.

33 Ashworth, "Sentencing", n. 25 above, at p. 1098. 
From an economic analysis perspective, the deterrent effect of the criminal law was famously expressed by Becker ${ }^{34}$ in terms of the relationship between the gain expected from regulatory breach, 35 the severity of sanction and the likelihood of apprehension. Thus, in basic terms, compliance will be ensured where the benefits of failing to comply with the law are exceeded by the costs of apprehension. ${ }^{36}$ Thus, the more severe the sanction and the higher the probability of apprehension, the greater the likelihood that an actor will be deterred from regulatory breach. Such a formulation presupposes that the object of deterrence is a rational profit maximiser, ${ }^{37}$ a presupposition that could be questioned most readily in the case of individual offenders. In relation to corporate entities, where often the prime objective is the creation of profit, it can more easily be assumed that increases in the economic costs of non-compliance will bolster the deterrent effect of the law.

An obvious response to Becker's analysis would be simply to increase the severity of sanction. From a public policy perspective, such a course of action may be seen as an attractive option; increasing the severity of punishment is a relatively low-cost option when compared with the costs associated with increasing the probability of apprehension, in terms of increases in surveillance, law enforcement activity etc. ${ }^{38}$ In essence, the economic costs of increasing the severity of sanction are marginal to the cost of increasing the probability of apprehension.

Increasing the severity of sanction may be seen as a deceptively attractive solution to regulatory non-compliance; however, more draconian penalties per se are far from a panacea. To concentrate extensively on the level of fines or the severity of sanctions in general is to adopt a rather blinkered approach to the question of how to reduce regulatory breach. An integral aspect of the deterrence formula is the probability of apprehension, thus, no matter how severe the sanction, if the probability of apprehension is zero, the cost of non-compliance would also be zero so that an actor would be provided with an economic justification for regulatory breach even where the expected gains from such violations are insignificant. In reality, no matter how remote the probability of apprehension, it will be greater than zero. Nevertheless, to concentrate simply on the severity of sanctions without also considering the probability of apprehension is a shortsighted approach. The importance of the likelihood of apprehension is illustrated by the following example: let us suppose that the expected gain from regulatory non-compliance is $f 100,000$. If the risk of apprehension is 0.5 (an implausibly high probability) then the penalty would have to be raised to $f 200,000$ so that the expected punishment cost equals the anticipated gain. ${ }^{39}$ The formula enunciated above is a simplification; the cost of noncompliance cannot be analysed simply in terms of the fine imposed but would also include

34 G Becker, "Crime and punishment: an economic approach" (1968) 76 Journal of Political Economy 161.

35 Becker's analysis is concerned with crime in general, however, the approach is capable of utilisation in all contexts, including regulatory non-compliance: "Although the word 'crime' is used in the title to minimize terminological innovations, the analysis is intended to be sufficiently general to cover all violations, not just felonies like murder, robbery, and assault, which receive so much newspaper coverage, but also tax evasion, the so-called white-collar crimes, and traffic and other violations." Ibid., p. 170.

36 This model has been varied by A Ogus and C Abbot, "Sanctions for pollution: do we have the right regime?" (2003) 14(3) JEL 283. Becker's formulation is expressed as $U<p D$ where $U$ is the profit from the offending activity, $p$ is the probability of apprehension and $D$ is the cost to the offender resulting from apprehension (at pp. 289-90).

$37 \mathrm{~J}$ Boswell and R Lee (eds), Economics, Ethics and the Environment (London: Cavendish 2002), at p. 1.

38 G Stigler, "The optimum enforcement of laws" (1970) 78 Journal of Political Economy 526, at p. 527.

39 J Coffee, "No soul to damn: no body to kick: an unscandalized inquiry into the problem of corporate punishment" (1980) 79 Michigan Law Review 386, at p. 389. 
costs less amenable to exact quantification, such as loss of reputation ${ }^{40}$ and legal representation expenditure. Further, the formula may be adjusted to take into account the fact that some actors may be particularly risk averse. ${ }^{41}$ In this example, deterrence is ensured where the cost of non-compliance at least equals the expected gain. Even if the probability of apprehension is extremely low, this magic figure could be achieved by an astronomically high fine, given the costs of increasing the likelihood of apprehension, Posner has postulated that an efficient outcome could be achieved by "a probability arbitrarily close to zero and a fine arbitrarily close to infinity". ${ }^{42}$ Such an approach is problematic for two reasons: first, an extremely high fine may discourage socially beneficial activities where there is a risk of accidental violation of the criminal law. ${ }^{43} \mathrm{~A}$ problem further compounded by the existence of strict liability for most environmental offences. Secondly, such high fines will often exceed the solvency of the particular offender.

It has been determined that the two variables of the deterrence formula are severity of sanction and likelihood of apprehension. As such, a detailed consideration of each is required.

\section{Sanctions for environmental crime}

\section{FINES}

The range of corporate sanctions available to the courts is limited; enforcement agencies are stymied to a considerable extent by the absence of imprisonment as a viable punishment. It is not the purpose of this article to consider in any detail the scope of the new sanctions advocated by Macrory and contained in the Regulatory Enforcement and Sanctions Act 2008: while most of the new sanctioning tools are novel in the sense that they may be imposed administratively without recourse to the courts, they fundamentally remain a form of financial penalty.

Academic literature and official publications alike are replete with assertions that the level of fines imposed by the courts for environmental crimes is insufficient to provide a meaningful deterrent; that is to say, polluters are not paying enough. To make such a claim is rather a trite assertion, as Coffee has opined, much of the literature on corporate punishment in general seems to consist of little more than such a contention. ${ }^{44}$ Indeed, within the specific context of environmental protection, it has become somewhat de rigeur to lament the low level of fines imposed by the courts. ${ }^{45}$ While increasing the severity of penalty would theoretically increase deterrence, the imposition of more punitive sanctions (increasing the level of fine for a particular regulatory infringement is the most obvious example) can only ever represent a partial solution to non-compliance for several reasons, not least, policymakers will invariably be subject to political constraints. Increasing the maximum fine for fly-tipping to $£, 500,000$ is unlikely to be a vote winner! A common explanation for the relatively low fines imposed for environmental crime is based on the fact that most regulatory breaches are subject to the jurisdiction of the magistrates' court or

40 P de Prez, "Beyond judicial sanctions: the negative impact of conviction for environmental offences" (2000) 2 Environmental Law Review 11. The effect of damaged reputation/public image will largely depend on the level of competition within the particular market. For example, a company which enjoys a monopoly is unlikely to be affected by adverse publicity.

41 See M Polinsky and S Shavell, "The optimal trade off between probability and magnitude of fines" (1979) 69(5) American Economic Review 880.

42 R Posner, "An economic theory of the criminal law" (1985) 85 Columbia Law Review 1193, at p. 1206.

43 Ibid.

44 Coffee, "No soul”, n. 39 above, at p. 388.

45 R Malcolm, "Prosecuting for environmental crime: does crime pay?" (2002) 14(5) Environmental Law and Management 289. 
crown court: courts which have little experience of both the technical aspects of many environmental laws and the nature and extent of potential environmental harm. ${ }^{46}$ Further, for many environmental offences, the maximum fine which may be imposed by a magistrates' court is $f 20,000$, a sum four times higher than the value of the statutory maximum fine on summary conviction for most other crimes. ${ }^{47}$ Thus, magistrates familiar with a maximum of $f, 5000$ may hesitate to impose greater fines, even where permitted to do so, in an area in which they have little experience. ${ }^{48}$

If one considers the approach of the higher echelons of the judiciary, the picture is somewhat mixed. In a handful of decisions, the Court of Appeal has concluded that the fine imposed by the first instance court was excessive: in $\mathrm{R} v$ Milford Haven Port Authority (The Sea Empress), ${ }^{49}$ a fine of $£, 4$ million imposed by Cardiff Crown Court was reduced to $f_{750,000}$; in R v Anglian Water Services Ltd, ${ }^{50}$ an initial fine of $f^{200,000}$ was reduced to $£, 60,000$; and in $R$ v Cemex Cement $L t d, 51$ a $f, 400,000$ fine was reduced to $f, 50,000$. On one level, these decisions may be seen as symptomatic of the lack of clear sentencing guidelines for environmental offences. ${ }^{52}$ Whether the approach of the Court of Appeal is unduly lenient is an arguable point; it could be contended that such drastic reductions undermine the message that environmental crime should be taken seriously. On the other hand, the reduced fines remain substantial. What is clear from the above cases is that the courts are influenced by the financial status of the offender. ${ }^{53}$ In $R \mathrm{v}$ Milford Haven Port Authority, the Court of Appeal was influenced by the fact that the port authority performed public functions and had limited avenues open to increase revenue. ${ }^{54}$ Similarly, in $\mathrm{R} v$ Cemex Cement, the appellant company had made a profit of just $f 39,000$ in 2006 . Setting the fine at a level which has serious financial consequences without forcing the defendant company into insolvency may achieve the objectives of specific deterrence but is more questionable in relation to general deterrence.

Setting the fine cognisant of the defendant's financial circumstances implicitly recognises the view that the imposition of substantial financial penalties creates externalities, summed up by the metaphor: "when the corporation catches a cold, someone else sneezes". 55 To punish a company is to also punish a range of stakeholders; the externalities of fines may be justified on the basis that to a greater or lesser extent, stakeholders (for example, shareholders) can at least sometimes be said to have received "unjust enrichment" from the benefits of corporate crime. ${ }^{56}$ However, in a world of imperfect competition, the costs of financial penalties will ultimately be transferred to

46 It has been contended that a magistrate may only see an environmental case every seven years: M Grekos, "Environmental fines: all small change" (2004) JPL 1330, at p. 1335.

47 Environmental Crime and the Courts, House of Commons Environmental Audit Committee, Sixth Report of Session 2003-04, at p. 9.

48 Ibid, at p. 11.

49 [2000] Env LR 632. Noted by M Davies, "Sentencing for environmental offences" (2000) 2 Environmental Law Review 195.

50 [2004] Env LR 10.

51 [2007] EWCA Crim 1759.

52 N Parpworth, "Environmental offences: the need for sentencing guidelines in the Crown Court" [2008] Journal of Planning and Environmental Law 18

53 By virtue of the Criminal Justice Act 2003, s. 164(3), the courts are required to take into account the financial status of the offender when setting the level of fine.

54 [2000] Env LR 632, at p. 647.

55 Coffee, "No soul", n. 39 above, at p. 401.

56 Ibid. 
consumers. ${ }^{57} \mathrm{~A}$ high degree of care needs to be taken when advancing such arguments. Any punishment administered to any type of offender will usually create externalities. For example, it would be nonsensical to argue against punishing a convicted murderer on the basis that there are family members who are financially dependent on him or her. Thus, taken to its logical extreme, the externalities argument could be used to justify never punishing a corporate offender. In respect of environmental regulation, Hawkins has caricatured the constituents of pollution control as "environmentalists" and "business", the former advocate greater restraints on economic activity in the interests of the environment, while the latter prefer a hands-off policy of non-intervention. ${ }^{58}$ The implicit role of the courts may thus be seen in terms of achieving a suitable balance between these competing aims in order to "preserve the sometimes fragile balance between the interests of economic activity ... and public welfare". ${ }^{59}$ As such, the courts are fully aware of the socio-economic consequences of corporate punishment ${ }^{60}$ and this creates serious difficulties if higher fines are seen as the main gambit in securing regulatory compliance.

While the general consensus of opinion is that fines for environmental crimes are commonly lower than they ought to be, the wisdom of such a view has been questioned by Parpworth et al. on the basis that any interest group is highly likely to regard the punishment administered by the courts to be inadequate where an offence is committed against an interest which the group seeks to promote or protect. ${ }^{61}$ As such, a fine which is less than the prosecutor and other interested parties would have liked may be seen as a "corrective" of the prosecutor's sectional view. ${ }^{62}$ Such a contention, it is submitted, has only limited force. While one would never advocate that the prosecutor (most often the Environment Agency) should be the ultimate arbiter of whether a particular sentence is adequate, one cannot simply dismiss the Environment Agency's opinion as biased or unbalanced. To look at the issue from a different perspective, it could equally be contended that the magistrates' assessment of the seriousness of an environmental crime will seldom, if ever, be fully informed given the paucity of environmental offences reaching the magistrates' court. In any event, three possible solutions to the problem of low fines have been suggested, namely the creation of a specialist environmental court ${ }^{63}$ or regulatory tribunal, ${ }^{64}$ increased training for the magistracy and judiciary on environmental issues ${ }^{65}$ and the use of minimum fines. All of which present difficulties.

The desirability or otherwise of an environmental court has been mooted for a considerable time. Arguably the most fruitful area of debate in this context is the

57 Coffee, "No soul", n. 39 above, at p. 402.

58 See Hawkins, Environment and Enforcement, n. 1 above, at p. 9.

59 Ibid.

60 To claim that the courts are influenced by the socio-economic consequences of their decisions should not automatically be construed as a criticism. For example, in the context of nuisance it has been asserted that the courts pay insufficient regard to such considerations. See S Tromans, "Nuisance - prevention or payment?" (1982) CLJ 87.

61 N Parpworth, K Thompson and B Jones, "Environmental offences: utilising civil penalties" (2005) JPL 560 , at p. 564.

62 Ibid.

63 H Woolf, "Are the judiciary environmentally myopic?" (1992) 4(1) JEL 1; R Carnwath, "Environmental enforcement: the need for a specialist court" (1992) JPL 799.

64 The Macrory report, n. 3 above, paras 3.54-60.

65 Parpworth, "Environmental offences", n. 52 above, at p. 30. 
jurisdiction of any such specialist court or tribunal. ${ }^{66}$ The logic underpinning the creation of an environmental court with criminal jurisdiction is simple. If it is accepted that the scarcity of environmental cases heard by magistrates is one reason for the low level of fines, then a court which exclusively dealt with environmental cases would fully appreciate the seriousness of environmental crime and administer a commensurate sentence. In a different regulatory context - health and safety - the issue has been succinctly summed up by Scott Baker J: "it is difficult for judges and magistrates, who only rarely deal with these cases, to have an instinctive feel for the appropriate level of penalty". 67

Practical and administrative difficulties notwithstanding, the establishment of a new environmental court is not entirely unproblematic. A commonly held perception, often resisted by environmentalists, is that environmental crime is not "real" crime. ${ }^{68}$ To transfer environmental offences from the magistrates' and crown courts would perpetuate the conception that environmental crime is different from other types of criminal conduct and therefore less serious and/or less worthy of society's indignation.

The second possible solution to the problems created by a magistracy which is arguably "environmentally myopic" (to paraphrase Lord Woolf LCJ) 69 is increased training of magistrates in an effort to enhance environmental awareness and expertise of the technical aspects of environmental law. This has occurred to a limited extent but again is not without difficulties. In particular, one could point to the apparent unfairness in allowing the environment agency, for example, to educate the magistracy on the importance of environmental protection without affording a similar opportunity to the regulated sector to emphasise the public benefits of the activities they engage in. ${ }^{70}$

The final solution to low fines is the creation of minimum or mandatory fines for environmental offences. ${ }^{71}$ Providing minimum statutory penalties for certain environmental crimes would create difficulties. Such a course of action would essentially strip the judiciary and magistracy of their long-held sentencing discretion. Although a common feature of the English legal system in the eighteenth century, in modern times mandatory sentences are the exception rather than the rule. ${ }^{72}$ Thus, increased use of mandatory fines would be at odds with the long-established tradition of prescribing maximum sentences only. Mandatory sentences in general are often utilised where the legislature intends to convey the clear message that certain proscribed conduct will not be tolerated. The most obvious contemporary example is the introduction of mandatory sentences for the possession of firearms following considerable public unease at the levels of gun-related crime in the UK. ${ }^{73}$ The imperative to deter certain types of conduct supersedes traditional mitigating sentencing factors such as previous good record, guilty pleas etc. The major difficulty of using such sentences is the creation of an entirely blunt instrument, which clearly has the

66 R Macrory and M Woods, Modernizing Environmental Justice: Regulation and the role of an environmental tribunal (London: Centre for Law and the Environment, University College London 2003) available at: www.ucl.ac.uk/laws/environment/tribunals/. The authors' advocate the establishment of an environmental tribunal with a non-criminal jurisdiction dealing with, inter alia, appeals against administratively imposed notices or the refusal to grant a licence or permit.

67 R v F Howe \& Son (Engineers) Ltd [1999] 2 All ER 249, at p. 254.

68 See n. 106 and accompanying text.

69 See Woolf, "Are the judiciary", n. 63 above.

70 See Parpworth et al., "Environmental offences", n. 61 above, at p. 564.

71 R Mushal, "Reflections upon American environmental enforcement experience as it may relate to postHampton developments in England and Wales" (2007) 19(2) JEL 201, at p. 215.

72 K Warner, "Mandatory sentencing and the role of the academic" (2007) 18 Criminal Law Forum 321, at p. 323.

73 See the Firearms Act 1968, s. 51A, inserted by the Criminal Justice Act 2003, s. 287. 
potential to create considerable unfairness. Such unfairness is more pronounced where the minimum sentence prescribed is custodial; where one is dealing with mandatory fines in an environmental regulatory context, objections based on unfairness may be tempered by the imperative to protect the environment. ${ }^{74}$ To mitigate such unfairness (perceived or real), Parliament may allow a court to avoid the minimum sentence where exceptional circumstances exist. The extent to which the sentence retains a mandatory quality is therefore contingent upon the breadth of the interpretation of "exceptional circumstances" proffered by the courts. Given the tradition of judicial discretion in sentencing, the courts may well promulgate an expansive interpretation of such a proviso thereby undermining the rationale of a mandatory fine.

The preceding section has illustrated that the possible solutions to the problem of low fines for environmental crime (assuming one accepts that fines for such offences are indeed lower than they ought to be) are not entirely unproblematic. Further, in practical terms, with the possible exception of increased training of the judiciary and magistracy, all would require primary legislation. Given such difficulties, one should consider alternatives to fines as a form of sanction.

\section{Alternatives TO FINES}

A possible solution to the externalities considered above is the use of custodial sentences even within the context of corporate regulatory breach. As Brickey has noted: "jail time is one cost of business that cannot be passed on to the consumer". ${ }^{75}$ Further, Glasbeek advocates the tactic of prosecuting individuals within in a company:

Every breach of a legal proscription requires the doing of an act by one or more persons. There is no reason that they should not be prosecuted as individuals.

This might have the desired effect of deterring them and others. ${ }^{76}$

While incarceration has been considered an option in American academic literature, ${ }^{77}$ the greater use of custodial sentences for corporate regulatory breach has never been advocated as a viable enforcement option in England and Wales. The use of custodial sentences in the context of corporate crime is not without precedent. The Environmental Protection Act 1990, section 157, and the Water Resources Act 1991, section 217, both provide that a director, manager, secretary or other similar officer may be prosecuted where a body corporate is guilty of an offence under the Acts and that offence is proved to have been committed with the consent or connivance of, or to be attributable to any neglect on the part of, any director, manager, secretary etc. of the body corporate.

74 Warner, "Mandatory sentencing", n. 72 above, at p. 330.

75 Brickley, "Environmental crime", n. 14 above, at p. 506.

76 H Glasbeek, "Why corporate deviance is not treated as a crime - the need to make "profits" a dirty word" (1984) 22 Osgoode Hall Law Journal 393. at p. 432.

77 M Minister, "Federal facilities and the deterrence failure of environmental laws: the case for criminal prosecution of federal employees" (1994) 18 Harvard Environmental Law Review 137, at p. 146; P Strom, "The United States Attorney's policy towards criminal enforcement of environmental laws" (1993) 2 South Carolina Environmental Law Journal 184, at p. 185; M Nolan and S Stahl, "The rules have changed, but the game remains the same: why the government has turned to criminal prosecution as a means of enforcing environmental laws" (1990) 7 Cooley Law Review 407, at p. 410. 
Although an extremely rare occurrence, individual directors have been subjected to a custodial sentence. ${ }^{78}$ However, given the need to prove consent, connivance etc. it would seem that the above provisions may only feasibly be utilised in the case of sole-traders or very small companies. Further, from the limited guidance provided by the courts, it appears that the imposition of a custodial sentence will only be considered where the case involves repeated breaches of an Act which are blatant and/or expose members of the public to hazardous substances. ${ }^{79}$

The idea which underpins the use of individual custodial sentences within the context of corporate crime is simple: if the upper echelons of a company are aware that if the organisation for which they are responsible engages in activities which constitute environmental crime, which in turn creates a significant possibility of imprisonment, then a real incentive is provided to put into place mechanisms to ensure full regulatory compliance. However, the increased use of incarceration for environmental crime is not without practical difficulties; the most obvious of which is an ever-burgeoning prison population. ${ }^{80}$ Such practical problems are easy to overstate; it is not suggested that imprisonment for environmental crime ought to be become commonplace but rather should not be ruled out as a possible sanction for the most serious of offences. Even this modest change of emphasis would require the statutory language used in provisions such as section 157 of the Environmental Protection Act 1990 to be modified. The requirement to establish consent, connivance etc. is an onerous hurdle to overcome unless dealing with the smallest of companies or sole-traders. Further, the greater use of incarceration for environmental offences would be politically highly contentious. First, from the perspective of public opinion, it is highly questionable whether environmental crimes are subjected to the same level of moral indignation that one would associate with other crimes. "Tough on environmental crime, tough on the causes of environmental crime" is an unlikely political slogan. Secondly, those on the right of the political spectrum are generally vociferously critical of what they see as lenient sentences in general. A criminal justice policy which imprisoned environmental offenders and imposed non-custodial sentences on muggers etc. would be hugely controversial and perhaps politically untenable.

In order to complete the sanctioning picture, it is necessary to consider the final weapon in the regulator's armoury, namely revocation or suspension of a licence or permit. Many activities which have the potential to cause environmental damage may only be undertaken with some form of permit, usually but not exclusively, issued by the environment agency. Waste management and water treatment works are two obvious examples, in addition, a vast range of industrial activities and processes require an IPPC (Integrated Pollution Prevention and Control) permit. Given that the acquisition of a permit is a condition precedent of engaging in the relevant activity, the revocation or suspension of a permit is tantamount to corporate capital punishment on the basis that the company in question cannot continue (legally) with the activity in question. Thus, in terms of deterrence theory,

78 E.g. R v Terence William Garrett [1997] 1 Cr App R 109, where the defendant was sentenced to 12 months' imprisonment for offences committed contrary to the Environmental Protection Act 1990, s. 33. See also ENDS Report 273 (October 1997), p. 45. The defendant was sentenced to two months' imprisonment following warnings from the Environment Agency in relation to an unbunded oil container from which oil escaped and polluted a nearby watercourse.

79 R v O'Brian and Enkel (2000) Env LR 653; the case involved the dumping of some 2000 lorry tyres contrary to the Environmental Protection Act 1990, s. 33. On the facts, the Court of Appeal overturned an eightmonth sentence on the basis that while the tyres were unsightly they posed no threat to public safety and were not a nuisance. As such the "custody threshold" was not passed.

80 See generally: www.hmprisonservice.gov.uk/resourcecentre/publicationsdocuments $/$ index.asp?cat $=85$. 
the revocation of a permit may be seen as a form of incapacitation. ${ }^{81}$ Given the draconian nature of this type of enforcement action, the revocation or suspension of a licence is located at the apex of the regulatory pyramid conceptualised by Gunningham et al. ${ }^{82} \mathrm{It}$ seems that revocation or suspension of a licence is a seldom-utilised option of last resort, only considered by enforcement agencies where criminal prosecution has proven to be ineffectual. ${ }^{83}$ As with the externalities associated with the imposition of fines or other financial penalties, an absence of competition within the market inhibits the extent to which revocation or suspension may be utilised as a sanction. For instance, where a sewage treatment company, for example, enjoys a near monopoly, the revocation of a licence or permit will have severe, even catastrophic, environmental consequences on the basis that no other company will be in a position to undertake the activities previously carried out by the miscreant firm. As such, the undesired consequences of suspension or revocation will often rule out such a course of action.

Within the context of deterrence, the main strength of utilising custodial sentences and the suspension/revocation of a licence is that such penalties are highly draconian in nature. However, this strength is also a weakness: in a climate where attitudes to environmental crime arguably remain ambivalent, such sanctions are too severe to be contemplated in all but the most serious of cases.

It is not submitted here that those who advocate larger fines or more severe sanctions are misguided. On the contrary, it may be safely assumed that recourse to stricter penalties so that the punishment administered by the courts is commensurate with the gravity of the particular offence would be a development welcomed by environmentalists and regulators alike. However, one should not overlook the importance of effective enforcement: it seems that the certainty of punishment appears to have a greater inhibitive effect on levels of crime than the severity of the punishment. ${ }^{84}$ Indeed, the general consensus of academic opinion seems to indicate that, given the psychological features of deterrence, subjective perception is critical, a viewpoint succinctly expressed by Williams and Hawkins: "The more the individual perceives legal sanctions as certain, swift, and/or severe, the greater the perceived cost of crime and thus the probability of deterrence." 85 In sum, in order to comprehend fully the concept of deterrence, one cannot simply analyse legal sanctions per se. Of equal, if not greater, importance is enforcement style, in particular, whether the enforcement policy adopted is likely to augment the perception that apprehension is more probable.

\section{Enforcement strategies: compliance versus deterrence}

It is not the purpose of this article to consider in detail the nature of enforcement styles adopted by regulators, save to say that two discernable regulatory strategies have been identified, namely compliance and deterrence. ${ }^{86}$ Rather than a strict dichotomy, one is dealing here with a spectrum of approaches so any particular enforcement policy may be located on a continuum with compliance and deterrence situated at either end. Compliancebased approaches are characterised by advice, persuasion and negotiation where criminal prosecution is used as a last resort. Deterrence-orientated strategies, as the name suggests,

81 Ogus and Abbot, "Sanctions", n. 36 above, at p. 294.

82 N Gunningham, P Grabosky and D Sinclair, Smart Regulation: Designing environmental policy (Oxford: Clarendon Press 1998), p. 397.

83 Ogus and Abbot, "Sanctions", n. 36 above, at pp. 288-99.

84 Jacob, "Deterrent effects", n. 32 above, at p. 63.

85 Williams and Hawkins, "Perceptual research", n. 27 above, at p. 547 (emphasis added).

86 See, generally, A Reiss, "Selecting strategies of social control over organisational life" in K Hawkins and J Thomas (eds), Enforcing Regulation (Boston: Kluwer-Nijhoff 1984). 
rely heavily on stringent enforcement and punishment of offenders. A third "hybrid" option has been identified, where regulation is "responsive" in the sense that the style adopted by the enforcement agency will vary according to the perception of the regulated actor. ${ }^{87}$ More recently, the concept of "really responsive" regulation has been promulgated whereby the regulator is not only responsive to the attitude of the regulatee but also to wider considerations such as, inter alia, the institutional environment and performance of the regulatory regime. ${ }^{88}$ In the recent past, one could confidently state that the qualitative studies undertaken on regulatory enforcement indicated that enforcement bodies in England and Wales relied predominantly on the compliance approach as an enforcement style. ${ }^{89}$ Whether compliance remains in the ascendancy is an open question, a question which requires empirical investigation. Baldwin, for example, refers to the "new punitive regulation" but acknowledges that aggressive rhetoric is not always matched by enforcement practice. ${ }^{90}$ From one perspective, the arguments advanced in this article are unaffected by the question of which enforcement style is more prevalent. If complianceorientated enforcement is still widely used, this article may be seen as advocating a subtle departure from such an approach. Alternatively, if a transition from compliance to more punitive methods of assessment is already underway, the contentions promulgated here may be used to support such developments.

The reasons which underpin compliance-based approaches are multifarious and will be considered under the following non-exhaustive headings: resource limitations, perceptions of the regulated community and the status of environmental crime.

\section{Resource limitations}

From a practical perspective, prosecution may be utilised as a tool of last resort because of resource limitations, that is enforcement bodies simply do not have the financial capability to prosecute every regulatory breach. The issue is succinctly summed up by Stigler: "There is one decisive reason why the society must forego 'complete' enforcement of the rule: enforcement is costly." 91 Those of a cynical persuasion may well view the Environment Agency's policy of "risk-based regulation" 92 euphemistically in light of funding constraints. As Grabosky has contended, "the question of efficiency looms even larger in the climate of fiscal austerity in which most governments operate today". 93 The predominance of strict liability for most environmental offences removes any necessity to prove fault. Nevertheless, the accepted wisdom is that criminal prosecution is a relatively costly and time-consuming option. As Mushal has contended:

With respect to enforcement, generally, toughness and speed are inversely related to one another - and there is a third element in that relationship: cost. The toughest sanctions are criminal, but criminal prosecution is not a speedy process and it has high resource costs ...94

87 I Ayres and J Braithwaite, Responsive Regulation: Transcending the deregulation debate (Oxford: Oxford Socio-legal Studies, OUP 1994).

88 R Baldwin and J Black, "Really responsive regulation" (2008) 71(1) MLR 59.

89 Hawkins, Environment and Enforcement, n. 1 above; B Hutter, The Reasonable Arm of the Law? The law enforcement procedures of environmental health officers (Oxford: Clarendon Press 1988).

90 R Baldwin, “The new punitive regulation” (2004) 67(3) MLR 351, at pp. 358-9.

91 Stigler, "Optimum enforcement", n. 38 above, at pp. 526-7.

92 Environment Agency, A Guide to Modern Regulation, available at: www.environment-agency.gov.uk.

93 P Grabosky, "Regulation by reward: on the use of incentives as regulatory instruments" (1995) 17(3) Law and Policy 257, at p. 258.

94 Mushal, "Reflections", n. 71 above, at pp. 206-7. 
Indeed, the greater use of administratively imposed monetary penalties is seen as an attractive option because they avoid recourse to the criminal courts. Such logic would seem to dictate that deterrence-based strategies, which rely more heavily on criminal prosecutions, are therefore less economically efficient than compliance-orientated approaches. Is this a safe assumption? Although an issue which requires detailed empirical exploration, it could be contended that negotiation, persuasion and advice, which are the hallmarks of any compliance strategy, are more time-consuming and therefore resource-depleting activities than the instigation of a criminal prosecution. For example, Nelken has postulated that those agencies with fewer personnel are more likely to adopt an "insistent" strategy:

The reason for the adoption of these different strategies is partly that those authorities with less manpower available are forced to use the brisker, less timeconsuming "insistent" methods (negotiating takes time). ${ }^{95}$

Further, the resource implications of instigating criminal prosecutions may be mitigated by the award of costs to the prosecuting authority. It is not suggested here that deterrencebased strategies are more inexpensive than those based on compliance, but that the tendency to assume the opposite, without extensive empirical data on which to base one's assertion, is premature.

\section{Perceptions of the regulated community}

Kagan and Scholz have identified three categories of non-compliant actor, namely, the amoral calculator, the political citizen and the organisationally incompetent. ${ }^{96}$ Complianceorientated strategies are perhaps partially explicable on the basis that most members of the regulated community are considered by enforcement agencies to be essentially socially responsible, as Hawkins has claimed: "Pollution control staff regard most dischargers as basically, if reluctantly, law abiding." 97 As such, the commonly held perception is that most violations occur as a result of ignorance or inadvertence. ${ }^{98}$ Thus, in terms of the tripartite analysis highlighted above, the presumption is that the regulated community is largely comprised of political citizens and, where breaches occur, they do so as a result of organisational incompetence. Very few organisations would therefore fall into the category of amoral calculator who deliberately violates the law on the basis that the gains/profits from such breaches will exceed the cost of apprehension. This perception of the corporation is clearly not universally accepted. Proponents of Marxist ideology would contend that the corporation, as an entity operating within a market system, is inherently criminogenic; the prime motivation of business is the creation of profit and this supersedes any other consideration, including legality. ${ }^{99}$ Such a contention is a radical, perhaps even an extreme perspective. Nevertheless, the paradigm which holds that the regulated sector is largely comprised of responsible citizens seems at odds with research conducted in 1998 where 38 per cent of Environment Agency field officers considered profit-seeking to be a major cause of environmental breaches. ${ }^{100}$ Of course, the regulated sector is keen to perpetuate a benign perception; many corporations go to considerable lengths to portray themselves as "green":

95 D Nelken, "Why punish?” (1990) 53(6) MLR 829, at p. 832.

96 R Kagan and J Scholz, "The criminology of the corporation and regulatory enforcement strategies" in Hawkins and Thomas, Enforcing Regulation, n. 1 above.

97 K Hawkins, "Bargain and bluff" (1983) 5(1) Law and Policy Quarterly 35, at p. 43.

98 J Rowan-Robinson and A Ross, "Enforcement of environmental regulation in Britain: strengthening the link" (1994) JPL 200, at p. 201.

99 See, generally, F Pearce, Crimes of the Powerful (London: Pluto Press 1976).

100 Cited in P de Prez, "Excuses, excuses: the ritual trivialisation of environmental prosecutions" (2000) 12(1) JEL 65, at pp. 68-9. 
In a nutshell, the corporate redefinition of the word "green" presented the public with a mild, less radical and de-politicised environmental vision along with less drastic responses to . . . environmental issues. ${ }^{101}$

In addition to perceptions of the regulated community, compliance-based enforcement is also influenced by what enforcement agencies consider to be their optimal role. In particular, regulators often refuse to perceive of their role as akin to that of the police but rather as primarily givers of guidance and advice. A corollary of this perception is that the power to instigate a criminal prosecution will only be utilised where other attempts to secure compliance have been exhausted. Pearce and Tombs have noted that those who reject the "regulator-as-policeman" strategy often invoke negative stereotypes of regulatory inspectorates, which became a feature of "anti-statist" rhetoric from the 1980 s onwards. 102 These negative stereotypes, which see an enforcement agency operating in an inflexible, legalistic manner, are implicit in certain aspects of the Macrory report. When considering the potential use of administrative penalties, the report suggests that the revenue generated from such penalties should not be retained by the relevant enforcement agency, to avoid "any perverse financial incentives"103 or the fostering of a "parking ticket mentality". 104 This mistrust of regulators is unsurprising. The overall focus of the contemporary regulatory reform debate is on how regulation may be modified so that administrative burdens on business are minimised. As such, it has been contended that compliance strategies "dovetail" with neo-liberal ideology. ${ }^{105} \mathrm{It}$ is not suggested that the regulated sector is largely comprised of malicious corporations, keen to increase profits at the expense of the environment, but rather it should not be automatically assumed that those subject to regulation are socially responsible. Of course, such a statement seems to do little more than subscribe to the concept of responsive regulation. However, it is submitted that regulators, as an initial starting point, could reverse their long-held presumption in favour of a more sceptical attitude toward those that they regulate.

\section{Status of environmental crime}

Writing in 1983, Hawkins contended that: "Though the law recognises no distinction, most people are unwilling to talk of crime when they discuss pollution."106 In 1992, Harris optimistically claimed that the enactment of the Environmental Protection Act 1990 heralded a shift in thinking so that environmental crime was no longer seen in morally neutral terms. ${ }^{107}$ The question here is: to what extent is environmental crime subjected to the same level of moral indignation that one associates with other forms of criminal conduct? In contemporary times, environmental issues have become increasingly

101 M Lynch and P Stretsky, "The meaning of green: contrasting criminological perspectives" (2003) 7 Theoretical Criminology 217, at p. 220 (emphasis added).

102 F Pearce and S Tombs, "Ideology, hegemony, and empiricism" (1990) 30 British Journal of Criminology 423, pp. 427-8.

103 The Macrory report, n. 3 above, at para. 3.45.

104 Ibid., at para.3.43.

105 R White, "Environmental issues and the criminological imagination" (2003) 7 Theoretical Criminology 483, pp. 486 and 497.

106 Hawkins, "Bargain and bluff”, n. 97 above, at p. 37. See also Stigler, "Optimum enforcement”, n. 38, at p. 526, who even questions the use of the word "criminal" to describe what he considers to be "trifling offences".

107 R Harris, “The Environmental Protection Act 1990 - penalising the polluter” (1992) JPL 515, at p. 516. 
pertinent. ${ }^{108}$ Nevertheless a considerable level of moral ambivalence is still evident when one considers environmental offences. The reasons for such ambivalence are no doubt numerous and complex.

The obvious question is, therefore: can the criminalisation of conduct which harms the environment be justified using traditional theories of criminalisation? Arguably the most widely accepted test of whether a particular type of conduct ought to be criminalised is the harm principle first promulgated by Mill ${ }^{109}$ and later developed by Feinberg. ${ }^{110}$ From an environmental perspective, the principle is usually expressed as an anthropocentric concept in terms of harm to other humans. It can clearly be determined that harm to the environment additionally causes, to a greater or lesser extent, harm to humans. One of the distinctive features of environmental crime is that often the offence will lack an immediate victim, or at least an immediate human victim. However, the harm principle is sufficiently malleable to incorporate less immediate forms of harm. ${ }^{111}$ Indeed, one commentator has considered the issue of environmental harm in apocalyptic terms to the extent that humankind's very existence is in jeopardy. ${ }^{112}$ Considered in this light the view that environmental crimes are fundamentally less serious than other crimes may be seen as puzzling, as Mushal has contended:

Some judges ... do not view them [environmental crimes] as being as serious as conventional crimes such as bank robberies and drug dealing ... even though the consequences of environmental crimes may be far broader, more severe and longer lasting. 113

As such, without considering each and every environmental offence and its potential harmful consequences, it is submitted that from a general theoretical standpoint, the designation of conduct which damages the environment as criminal may be justified on the basis of the harm principle. Given that the proscription of activities which cause environmental damage may be supported using the traditional test of criminalisation, one may question why environmental crime is considered inherently less serious than other forms of criminal behaviour.

\section{The potential benefits of deterrence-oriented enforcement}

The preceding sections of this article have sought to establish two propositions. First, that to concentrate simply on the severity of sanction is only ever likely to represent a partial solution to the problem of regulatory breach. Secondly, the assumptions on which compliance-orientated strategies are based can be questioned, if not totally undermined.

108 A survey carried out on behalf of the Department for Environment, Food and Rural Affairs discovered that, of the issues people think government should be dealing with, the environment $(19 \%)$ was the fourth most commonly mentioned behind crime (49\%), health (47\%) and education (36\%): 2007 Survey of Public Attitudes and Behaviours Toward the Environment, available at www.defra.gov.uk/environment/statistics/pubatt/download/pubattsum2007.pdf.

109 J S Mill, “On liberty” in S Collini (ed.), Mill, On Liberty and Other Writings (Cambridge: CUP 1989).

110 J Feinberg, Harm to Others (New York: OUP 1984); Offense to Others (New York: OUP 1985); Harmless Wrongdoing (New York: OUP 1990).

111 A von Hirsch, "Extending the harm principle: 'remote' harms and fair imputation" in A Simester and A Smith (eds), Harm and Culpability (Oxford: Clarendon Press 1996), pp. 259-76, has questioned the use of the harm principle as a justification for the criminalisation of remote harms and suggests "fair imputation" as a possible alternative.

112 C Cullinam, Wild Law (Claremont, SA: Siber Ink/Gaia Foundation 2002), at p. 15, states: "Human societies are savaging Earth. Right now the human societies that currently dominate our planet are precipitating what is being described as the sixth mass extinction."

113 Mushal, "Reflections”, n. 71 above, at pp. 211-12. 
The role of regulatory enforcement bodies such as the environment agency and local authorities is multifaceted and clearly includes the giving of advice and guidance. Further, one cannot deny the importance of maintaining a constructive relationship with the regulated sector. ${ }^{114}$ However, an over-reliance on compliance-oriented enforcement strategies is problematic. First, compliance approaches have the potential to undermine transparency, the "power to be lenient [also] is the power to discriminate". 115 Second, reliance on compliance methods creates the danger of an overly cosy relationship between regulators and those regulated, i.e. regulatory capture. In a study of regulatory compliance within the context of factory legislation it has been contended that one effect of "underenforcement" is that the relevant form of illegal activity becomes "conventionalised". 116 If the regulated sector is aware (and one can assume that it will be) that the relevant enforcement authority adopts a strategy based on co-operation, advice and persuasion, they are likely to "test the water" by engaging in activities which do not conform to the standards set in legislation, safe in the knowledge that they will be given a second chance should the violations be brought to the attention of an enforcement agency. The concept of "riskbased regulation" 117 is problematic in this context; if a regulatee is not considered to pose a high risk of non-compliance, any illegal activity may remain undetected for a considerable time. Proponents of compliance-orientated approaches sensibly argue for persuasion and negotiation against a backdrop of potentially tough enforcement via the criminal law, i.e. regulators "will be able to speak more softly when they are perceived as carrying big sticks". 118 However, where prosecution is a relative rarity, this threat has the potential to become utterly empty.

In terms of deterrence theory, it is axiomatic that the likelihood of apprehension is a crucial factor. However, the probability of apprehension is a broad concept with three distinct elements. First, there is the likelihood that a given regulatory transgression will actually be brought to the attention of an enforcement agency. Second, if an enforcement body is aware of an alleged breach, then a decision has to be taken whether or not to launch a prosecution. Finally, if a prosecution is instigated and a not-guilty plea is put forward, the additional likelihood of a conviction has to be considered. A compliance-orientated enforcement style, where recourse to prosecution is utilised as a last resort, clearly has the potential to undermine the deterrent effect at stage two of the above tripartite analysis. Those who are contemplating transgressing the law may well take into account the fact that even if an illegal activity is discovered, the probability of the relevant enforcement agency instigating a criminal prosecution is relatively small. One can safely assume a correlation between the likelihood of prosecution and the extent of any deterrent effect. Given that the general academic consensus seems to be that the perceived likelihood of apprehension has a greater influence on the deterrent effect than the severity of sanction, ${ }^{119}$ a move towards a more deterrence-orientated style of enforcement has the potential to augment the

114 C Abbot, "The regulatory enforcement of pollution control laws: the Australian experience" (2005) 17(2) JEL 161, at p. 165.

115 McCleskey v Kemp, 481 US 279, 297, 312 (1987) (quoting K C Davis, Discretionary Justice: A preliminary inquiry (Baton Rouge: Louisiana State UP 1969), p. 170).

116 W Carson, "Some sociological aspects of strict liability" (1970) 33 MLR 396.

117 See, generally, J Black, "The emergence of risk based regulation and the new public risk management in the UK" (2005) PL 512. For a brief critique of risk-based regulation, see Baldwin and Black, "Really responsive regulation", n. 88 above, at pp. 66-7.

118 Ayres and Braithwaite, Responsive Regulation, n. 87 above, at p. 6.

119 For a comprehensive review of relevant literature, see A von Hirsch, A Bottoms, E Burney and P Wikström, Criminal Deterrence and Sentence Severity: An analysis of recent research (Oxford: Hart Publishing 1999). 
perception that the probability of apprehension is higher, thereby bolstering the deterrent effect of the law.

It could be argued that deterrence-orientated strategies are likely to prove counterproductive on the basis that greater recourse to prosecution is likely to create an "organised culture of resistance". ${ }^{120}$ Baldwin has cogently identified the possible shortcomings of deterrence or punitive-based enforcement; ${ }^{121}$ most notably, it is contended that corporations may respond to "punitive risks" irrationally and may be poorly equipped to deal with or anticipate such punitive risks and the effects of sanctions. ${ }^{122}$ Further, Baldwin contends that even where a corporation acts rationally (or at least along rational lines), it cannot be assumed that this will lead to compliance. ${ }^{123}$ For example, the prospects of future punitive sanctions may induce corporations merely to reduce the impact of any sanction by, inter alia, taking out insurance. ${ }^{124}$ In relation to the insurance point, one could question the extent to which it is desirable to allow insurance against the risk of fines; ${ }^{125}$ in any event while a simplistic analysis would seem to suggest that the availability of insurance undermines any deterrent effect, the nature of the actuarial analysis is such that those corporations with internal structures prone to non-compliance will be required to pay higher premiums. Further, it is safe to assume that, after a corporation has invoked an indemnity clause on one occasion, future insurance premiums are likely to rise considerably.

The case against punitive forms of regulation articulated by Baldwin is underpinned by the view that corporations have difficulty in responding to punitive risks:

It may be the case that sanctions, when imposed, do have an impact well beyond the quantum of a fine but such secondary impacts may stimulate extremely low levels of ex ante compliance-seeking behaviour because they are very poorly anticipated. ${ }^{126}$

In response to this assertion, one may point to the intuitive view that corporations (and indeed individuals) will often experience difficulty in accurately assessing new risks or increases in risk. Thus, if within a particular regulatory context, a shift of emphasis is made so that punitive risks become more prevalent due to an increase in the likelihood of prosecution, an initial period of confusion is unsurprising. However, assuming a sufficient level of transparency, once the new policy has "bedded in", a corporation may be able to anticipate and respond to any punitive risks in a more coherent and informed manner.

If one assumes that the majority of the regulated sector is basically law-abiding and that transgressions occur due to inadvertence, carelessness or ignorance, then a strategy focused on advice and guidance may be seen as particularly suitable. However, it is not submitted that enforcement bodies ought to adopt a "zero tolerance" approach, but rather that a subtle but noticeable shift towards deterrence could potentially have a greater preventative effect. Even if one accepts the view that most violations are non-deliberate, a move towards deterrence could still be justified. First, can it be contended that the ignorant or inadvertent company is free of culpability? Perhaps. The stock response would be that with the

120 Grabosky, "Regulation by reward", n. 93 above, at p. 263.

121 Baldwin, "New Punitive", n. 90 above.

122 Ibid., at p. 370.

123 Ibid.

124 Ibid., at p. 371. For a critique of the practice of insuring against fines in the context of marine pollution, see O Lomas, "The prosecution of marine oil pollution offences and the practice of insuring against fines" (1989) 1 JEL 48.

125 See the dicta of Rowlatt J in R Leslie v Reliable Advertising etc. Agency Ltd [1915] 1 KB 652, at pp. 658-9, and Denning $\mathrm{J}$ in Askey v Golden Wine [1948] 2 All ER 35, at p. 38.

126 Baldwin, "New punitive”, n. 90 above, at p. 372. 
ever-burgeoning body of environmental regulation to which business is subject, maintaining a high level of awareness of one's legal responsibilities is an onerous task. Such arguments are worthy of rejection for two reasons. First, such a contention comes close to violating the fundamental principle that ignorance is no defence. Second, compliance strategies developed in a pre-internet age, where information did not flow as freely as today. In a contemporary context, regulators go to considerable lengths to publicise new and existing legal obligations. The Environment Agency's NetRegs is the most obvious example. ${ }^{127}$ In light of the availability of numerous avenues of information, can it really be contended that the ignorant or unintentional transgressor is free of blame? It is submitted that a move towards deterrence-based strategies would ultimately not only provide a greater retributive element, where the polluter is a recalcitrant offender, but would also reduce the likelihood of less culpable breaches. If many offences are committed simply as a result of human error or inadvertence, then an increase in prosecutions would help to publicise the extent of the regulated communities' legal obligations. Further, it is logical to assume that a desire to avoid a potentially punitive sanction would encourage the education and training of employees. Those who advocate the greater use of deterrence-based enforcement as a means of influencing the internal procedures of corporations may well gain encouragement from qualitative research conducted by Baldwin: "For many firms interviewed, the imposition of a first punitive sanction produced a sea-change in attitudes." 128 So much for specific deterrence - one may question whether the same holds true for general deterrence. The answer seems to be in the affirmative:

Of the three-fifths of respondents who were aware of firms in their sector being punitively sanctioned, 57 per cent stated that this had impacted very strongly on their own management of punitive regulatory risks. ${ }^{129}$

It may be the case that many environmental offences are committed as a result of accident, mechanical malfunction, operator incompetence or even unforeseeable events. For example, in Empress Car Company (Abertillery) Ltd v National Rivers Authority, ${ }^{130}$ the House of Lords confirmed the defendant's liability, notwithstanding that the constituents of the relevant offence were brought about by an unidentified vandal. The potential effectiveness of deterrence is based on the assumption that a rational corporation would respond by putting in place measures which reduce the likelihood of vandalism in the future. The obvious problem, notwithstanding that rationality cannot automatically be presumed, is that a company will be subject to limitations (financial or otherwise) in terms of reducing the risk of even inadvertent non-compliance. However, it is not suggested that deterrencebased enforcement is in any way a panacea; rather it is argued that deterrence is capable of performing an internal educative and managerial function. One should not rule out a particular approach merely on the ground that it will not prove effective in all cases.

Preceding sections of this article have attempted to analyse some problematic aspects of an approach which simply concentrates on the severity of sanction as a means of increasing the deterrent effect of regulatory law. It is contended that a move towards deterrenceoriented strategies would attenuate, to a greater or lesser extent, many of the difficulties highlighted. First, the oft-quoted reason for the problem of low fines for environmental offences is the inexperience of the magistracy and judiciary in dealing with environmental

127 NetRegs is an Environment Agency website which aims to provide detailed information to businesses in the UK on the extent of their environmental legal obligations. Companies may also subscribe to free NetRegs e-alerts which highlight new developments: www.netregs.gov.uk/netregs/.

128 Baldwin, "New punitive", n. 90 above, at p. 361.

129 Ibid.

130 [1998] Env LR 396. 
crime. A strategy based on deterrence, where recourse to criminal prosecution is made more readily, would increase the number of cases heard by the magistrates, which would, in turn, facilitate awareness of environmental issues and the technical aspects of environmental offences. In effect, an increase in the number of cases heard by the courts would go some way towards breaking the "vicious circle" highlighted by Watson. ${ }^{131}$ Thus, the overall level of fines could increase organically, without the need for increased training of the magistracy and judiciary and/or the imposition of mandatory fines.

Compliance strategies may be partially justified on the basis that a softer enforcement approach is appropriate on the grounds that environmental crimes are subject to moral ambivalence. Put another way, where an illegal act is the subject of moral indignation, it is extremely difficult to imagine an enforcement agency adopting a strategy of advice, persuasion and negotiation. For example, one can only imagine the public outrage and media hysteria if the police merely advised paedophiles how to avoid abusing children and the Crown Prosecution Service prosecuted only where all other avenues had failed to prevent the undesired conduct. This example is clearly an extreme one; one would never equate the moral culpability associated with paedophilia with crimes which damage the environment. Nevertheless, an amoral conception of environmental crime creates a climate where compliance-orientated approaches are able to gain ascendancy. The traditional argument is that one of the causes of the prevalence of compliance styles is a morally neutral conception of environmental crime. However, one could question whether this view reverses cause and effect; could it not be contended that compliance-orientated enforcement is a cause of the moral ambivalence associated with environmental crime? As Nelken had postulated:

Part of the difficulty of resolving this problem is often said to result from the uncertainty about what the public feels concerning these offences. But it could well be argued that community perceptions of these offences is as much an effect as a cause of the method of enforcement used. ${ }^{132}$

In this context, the offence of driving under the influence of alcohol is a suitable analogy; as with many environmental crimes, the offence is inchoate in the sense that a crime is committed even if the standard of driving has not been noticeably impaired, i.e. the particular activity is proscribed because of the potential to cause serious harm notwithstanding that the harm has not actually occurred. More importantly for present purposes, driving while under the influence of alcohol is an activity which has undergone a transition from public indifference to moral indignation:

Not only is it less common these days to hear the view expressed that drivers caught with excess alcohol have just been "unlucky", but the fact that majority opinion in this country is currently in favour of random breath testing also suggests that drink-driving may be condoned to a lesser extent that formerly. ${ }^{133}$

Thus, those who espouse the view that environmental crime ought to be treated more seriously may gain encouragement from the extent to which the law is capable of influencing (albeit slowly) public perception. A transition from compliance to deterrencebased enforcement strategies has the potential to modify progressively how the public perceive of environmental crime. Alternatively, if it is accepted that public perception is gradually changing so that environmental crime is decreasingly seen in morally neutral terms, greater use of deterrence-orientated enforcement could accelerate such change. The

131 Watson, "Environmental offences", n. 22 above, at p. 199.

132 Nelken, "Why punish?", n. 95 above, at pp. 831-2.

133 C Corbett and F Simon, "Police and public perceptions of the seriousness of traffic offences" (1991) 31 British Journal of Criminology 153, at p. 154. 
moral status and public perception of environmental crime is of fundamental importance, not only from a theoretical standpoint but also a practical perspective. If policymakers are cognisant of changing attitudes to the environment, this will place considerable political constraints on any attempts to reduce funding of enforcement agencies and/or would increase considerably the lobbying power of those who argue in favour of the dedication of greater resources to enforcement activity.

One may predict with a reasonable degree of certainty that a move towards more deterrence-orientated enforcement will be resisted by the regulated sector; business will no doubt advance the familiar argument that most regulatory breaches occur through inadvertence and ignorance. Indeed, the use of more coercive methods may be seen as running counter to the trend of using more indirect means, such as economic instruments, in order to achieve environmental objectives. A laissez-faire conception of state intervention, borne out of antipathy toward bureaucracy and/or the allure of market instruments, ${ }^{134}$ would seem to suggest that non-coercive means are preferable to coercive ones. The distinction between tools which encourage desirable conduct and tools which punish undesirable conduct is often difficult to draw. ${ }^{135}$ Nevertheless the criminal law has a unique stigmatising effect and sends the clear message that certain types of conduct will not be tolerated by society. ${ }^{136}$ Neiman argues strongly in favour of the use of more coercive methods of achieving policy objectives but accepts that "heavy-handedness" in government is only acceptable within a democracy. ${ }^{137}$ It is submitted that democracy is a necessary but not sufficient condition for the greater use of deterrence-based enforcement strategies. In order to provide a clear justification for the use of more insistent enforcement a number of developments would be required. First, in the interests of fairness and balance, if one is to make greater use of the "stick" then a corresponding increase in the use of the "carrot" would seem appropriate. There is no logical reason why the use of incentives to achieve regulatory compliance and the increased use of prosecution and punishment should be seen as mutually exclusive: "a regulated entity may be simultaneously offered a carrot and threatened with a stick". 138 The use of incentives or rewards to achieve environmental objectives may take many forms (a comprehensive discussion of such policy instruments is beyond the scope of this article). ${ }^{139}$ However, far from being contradictory, the use of such facilitation strategies may actually compliment and enhance deterrence-based enforcement strategies. For example, one very obvious objective of waste management is to ensure that waste is disposed of responsibly in a manner which minimises, as far a is possible, environmental damage. ${ }^{140}$ In order to further this objective, a two-pronged approach is used: first, facilitate the appropriate disposal of waste via the operation of a network of civic amenity sites ${ }^{141}$ and the provision of refuse collection services; ${ }^{142}$ secondly, criminalise any unauthorised disposal of waste. ${ }^{143}$ Thus, those who are prosecuted for

134 M Friedman, Capitalism and Freedom (Chicago: University of Chicago Press 1967).

135 Brigham and Brown, "Distinguishing penalties", n. 19 above.

136 H L A Hart, The Concept of Law 2nd edn (Oxford: Clarendon Law Series, OUP 1994), p. 39.

137 M Neiman, “The virtues of heavy-handedness in government” (1980) 2(1) Law and Policy Quarterly 11, at p. 17.

138 Grabosky, "Regulation by reward", n. 93 above, at p. 271.

139 See, generally, G Balch, “The stick, the carrot, and other strategies” (1980) 2(1) Law and Policy Quarterly 35.

140 See Art. 4 of the Waste Framework Directive (75/442/EEC).

141 Environmental Protection Act 1990, s. 51, places a duty on waste disposal authorities (commonly a local council or county council) to provide sites where waste may be disposed of.

142 Environmental Protection Act 1990, s. 45, places a duty on waste collection authorities (commonly a local authority) to provide waste collection services.

143 The crime of unauthorised depositing of waste, commonly known as fly-tipping, is an offence by virtue of the Environmental Protection Act 1990, s. 33. 
fly-tipping can hardly complain that they had no choice, given the existence of mechanisms designed to facilitate compliance with the law. In this sense, the provision of strategies designed to encourage or incentivise compliance provide a clear normative basis for the speedier recourse to prosecution associated with deterrence-orientated enforcement strategies. In summary, the use of the stick may be more readily justified when the regulated entity has first been offered the carrot.

The increased use of facilitation strategies would provide a theoretical justification for the strict enforcement of the law when sections of the regulated sector fail to take advantage of such mechanisms and transgress the law. The greater use of deterrence-based enforcement would also require changes of a more practical nature. The accepted wisdom is that recourse to prosecution is more costly than more insistent methods; an earlier section of this article has questioned such wisdom on the basis that the assumption is made without reference to detailed empirical evidence. However, given that the likelihood of apprehension is a crucial element of the deterrence formula, additional resources would be required to increase surveillance activity etc. Furthermore, if a move towards deterrence is made, the increased use of facilitation strategies would obviously create additional costs for enforcement agencies. Numerous ways of providing additional resources to enforcement agencies exist; perhaps the most obvious is to increase the funding such bodies receive from central government. This could be achieved either through the diversion of existing funds or through increases in taxation - both options would be politically contentious. An alternative is to hypothecate the fines received from environmental offences. The Macrory report conspicuously rejected the hypothecation of the proceeds of administratively imposed monetary penalties on the basis that to allow enforcement agencies to retain the income generated from such penalties has the potential to create "perverse financial incentives". ${ }^{144}$ However, the use of hypothecation is not without precedent in environmental law. For example, following amendments to the Noise Act 1996, local authorities may now retain the proceeds of fixed penalty notices imposed for the night noise offence created by the Act providing those receipts are used to fund "qualifying functions", i.e. are utilised to fund noise-related enforcement activity. ${ }^{145}$ One may question, therefore, why local authorities are trusted not to adopt a "parking ticket mentality" in relation to the exercise of noise-related enforcement powers. Perhaps the answer lies in the fact that the Noise Act 1996 is only applicable to dwellings and licensed premises (public houses, night clubs etc.), which reduces considerably the likelihood that the issue of fixed penalty notices will place an onerous financial burden on business. However, the apprehensive attitude to hypothecation evident in the Macrory report cannot be solely explained by a concern not to interfere too greatly with economic interests. It is possible that such a development could lead to the misuse of prosecutorial discretion. An enforcement agency, cognisant of funding constraints, may well target those offenders who have the financial resources easily to pay fines and/or administrative monetary penalties; solvent offenders are not necessarily the most serious polluters and, as such, the hypothecation of penalty receipts may operate counter-productively, with the environment suffering as a result. Nevertheless, if policymakers are serious about reducing environmental regulatory breaches then perhaps they need to place more faith in enforcement agencies to exercise a degree of common sense. The introduction of hypothecation could be brought about by an enabling statute, granting the Secretary of State the power to enact secondary legislation. If, after a sufficiently long probationary period, it was demonstrated that enforcement agencies were abusing their prosecutorial discretion by concentrating

144 The Macrory report, n. 3 above, at para. 3.45.

145 Noise Act 1996, s. 9(4A). 
predominately on "easy targets" then the ability to retain the proceeds of fines etc. could be easily revoked by a further statutory instrument.

At numerous points throughout this article phrases such as "shift of emphasis" and "a move towards deterrence-orientated approaches" have been used. This raises the obvious question of how such a development could be effected. As with any prosecutorial regime, the enforcement of environmental law operates within a highly discretionary system: there is scant legal control or oversight of the use of prosecutorial powers endowed to enforcement agencies. ${ }^{146}$ It is not in any way suggested here that prosecutorial powers ought to be more extensively regulated or more freely challenged. Even if such a course was considered desirable, effectively regulating prosecutorial decision-making is extremely problematic. ${ }^{147}$ The current government favours the use of voluntary codes of conduct as a means of exercising a degree of control over enforcement practice. The most obvious example is the Enforcement Concordat, ${ }^{148}$ which has been adopted by over 96 per cent of local and central government bodies with enforcement functions. The principles of good enforcement policy contained in the Enforcement Concordat are clearly geared toward a compliance-orientated approach with little or no regard paid to the dangers of regulatory capture and the importance of the probability of apprehension. Perhaps an amended concordat could be the first stage in any transition from compliance to deterrence. In any event, the main purpose of this article is to consider the arguments which may be used in support of more deterrence-orientated enforcement, i.e. we are concerned with the question of whether a deterrence approach would bolster the preventative aspects of environmental criminal law. How any changes in enforcement style would be actuated is a separate question for another time.

\section{Conclusion}

The desirability of preventing environmental harm is beyond doubt: as such, the preventative principle is universally accepted as a sound basis for environmental laws. Further, it is generally acknowledged that the imposition of reactive criminal liability may operate preventatively via the concept of deterrence. This article has focused on how the deterrence effect and, by extension, the preventative effect of regulatory criminal law may be bolstered. A common response to the question of how one reduces regulatory breach is to increase the severity of sanction; indeed, academic literature is replete with assertions that the fines imposed for environmental crime are lamentably low. It is not suggested here that an overall increase in the severity of sanction, so that the punishment imposed is commensurate with the gravity of the particular offence, would be an unwelcome development; rather it is submitted that the severity of punishment may only ever represent a partial solution to non-compliance. A preoccupation with sanctioning may allow one to overlook the fundamental importance of the likelihood of apprehension; here the enforcement style adopted by enforcement agencies is critical. The assumptions on which compliance-orientated enforcement strategies are based may be questioned if not totally undermined, as such one may consider the potential benefits of deterrence-based

146 The Deregulation and Contracting Out Act 1994, s. 5, vested in a Minister of the Crown the power to improve enforcement procedures. The provision was repealed by the Regulatory Reform Act 2001, s. 12(1), which itself was repealed by the Regulatory Reform Act 2006, Sch. 1, para. 1.

147 See, generally, S Bibas, "Prosecutorial regulation versus prosecutorial accountability", University of Pennsylvania Law School: Scholarship at Penn Law, Paper 253 (5 December 2008): http://lsr.nellco.org/upenn/wps/papers/253; J Vorenberg, "Decent restraint of prosecutorial power"(1981) 94 Harv L Rev 1521.

148 Enforcement Concordat: Good practice guide for England and Wales, DTI, available at www.berr.gov.uk/files/file10150.pdf. 
enforcement. Speedier recourse to criminal prosecution would help increase the number of environmental cases heard by the courts which would in turn publicise the extent of the regulated sectors' legal obligations. Further, the use of more insistent methods of enforcement has the potential gradually to modify the public perception of environmental crime. The increased use of deterrence-orientated enforcement could be more easily justified if a corresponding increase in the use of facilitation strategies is actuated. Finally, serious thought ought to be given to the introduction of hypothecated penalty receipts to mitigate any potential cost implications of the change of emphasis advocated by this article.

In essence, the theme of this article could be summarised in the following manner: mainstream criminological opinion, as influenced by empirical evidence, strongly suggests that in terms of the two integral deterrence variables, the likelihood of apprehension has a greater influence on deterrence than the severity of sanction. Thus, one could consider how the probability of apprehension may be actually increased, or, given that deterrence is a psychological phenomenon, how the perception that apprehension is more probable could be bolstered. It has been argued that, in terms of approaches to regulation, deterrence-orientated enforcement has the potential to increase the dissuasive aspects of environmental criminal law, which a fortiori could further the aims of the preventative principle. 